AFRICAN

\title{
China-Africa humanistic education co-operation: a road toward cultural diversity*
}

\author{
by Jian Junbo** \\ Institute of International Studies, Fudan University
}

Shanghai, China

\begin{abstract}
For nearly six decades, China-Africa education co-operation has made great progress laying a stronger foundation for a better partnership between the partners and, to some extent, the promotion of African capacity-building. Nonetheless, considering the cultural domination of the West in the world and a cultural crisis that both China and African countries are encountering, technique-oriented Sino-African education co-operation should be accompanied with a stronger co-operation on humanistic education, so as to meet the needs of cultural diversification in a global age. This article argues that it is just the time for China and Africa to address the need of pursuing their closer humanistic education co-operation to counterbalance the Western cultural hegemony and promote diversification of cultures in the world, although in this bi-lateral co-operation Western culture should never be a targeted enemy.
\end{abstract}

*This paper, as part of the research project titled "Emerging Powers in Africa: a New South-South Co-operation Possible?"(project number: 14FSSX03YB), is funded by the 'African Research Fund 2014" of Zhejiang Normal University, China. The author will extend his appreciate to Professor Liu Yongtao whose suggestions and comments are very helpful for this paper's writing.

** Dr. Jian Junbo is an Associate Professor at the Institute of International Studies at Fudan University. 


\section{Introduction}

Sino-African educational co-operation has made great progress since the People's Republic of China (PRC) was established in 1949. However, it does not mean this progress is much associated with or has significantly pushed the world's cultural diversification. This is mainly due to the reality that technique-oriented educational co-operation between China and Africa has outnumbered their humanity-oriented cooperation.

This article will focus on the humanistic education co-operation between China and Africa over the past few decades, analysing its achievements and challenges and searching for feasible approaches to promote the humanistic education co-operation that can contribute to the diversity of cultures in the world. Taking this into account, the article is divided into three sections. The first section will discuss the theoretic role of humanistic education between China and Africa in its contribution to the cultural diversification in the world. In the second section, the social practices, achievements and limitations of China-African humanistic educational co-operation will be examined and analysed empirically. The road to cultural diversification in Africa and China through education co-operation in the humanistic field will be elaborated on in the third section.

\section{Crisis of cultural diversification in China and Africa and their cultural independence}

\section{Crisis of national/local culture in China and Africa}

The importance of cultural diversity for humankind is self-evident. The respect and protection of cultural diversity is not simply part of the road to economic prosperity and political stability at national, regional and global levels, but also arguably the precondition of the survival of humanity. The Universal Declaration on Cultural Diversity, issued by the United Nations Educational, Scientific, and Cultural Organisation (UNESCO) in 2001, highly values cultural diversity by stating that:

(A)s a source of exchange, innovation and creativity, cultural diversity is as necessary for humankind as biodiversity is for nature. In this sense, it is the common 


\section{AFRICAN \\ EAST-ASIAN \\ AFFAIRS \\ THE CHINA MONITOR}

heritage of humanity and should be recognised and affirmed for the benefit of present and future generations. (UNESCO, 2001)

It also stated that cultural diversity:

Widens the range of options open to everyone; it is one of the roots of development, understood not simply in terms of economic growth, but also as a means to achieve a more satisfactory intellectual, emotional, moral and spiritual existence. (UNESCO, 2001)

The implication of these words is that both the equality of different cultures and the maintenance of their distinctions should be respected. Cultural diversity is both desirable and achievable if local and national cultures in the same region are recognised by each other and treated equally by political systems ${ }^{1}$. That is, the cultural diversity can be empirically considered as a case if each culture can be independent from any heterogeneous cultures.

Nonetheless, the cultural diversity and many countries' local and national cultures' independence have long been undermined by colonialism and the spread of western culture embedded in the process of industrialisation, and especially challenged lately by a new wave of globalisation since the 1990s. As for China and Africa, their national/local cultures are particularly undermined by a series of historical episodes such as Westernisation, de-tradition movements, colonisation, and globalisation.

As for China, huge cultural crises emerged in the late 19th century when western powers entered this old empire and Japan defeated China in 1895 (Leung Kai Chiu, $1993)^{2}$. From then on the Chinese elite has never given up on their search for ways of generating wealth and saving a poor "central kingdom", hoping to resume the glory of Chinese culture. Nonetheless, since the May 4th Movement in 1919, one alternative road to restore a rich and strong China- overall westernisation, defined as embracing "democracy and science"- was broadly accepted by Chinese elites, despite the early failure of a top-down "Westernisation Movement",

After the People's Republic was founded, the Chinese Communist Party (CCP) as a ruling party partly took over the idea of overall Westernisation, in the sense that it set 
Marxism and socialism as dominant ideologies. After the end of the Cultural Revolution (1966-1976) which led to immeasurable catastrophe for Chinese culture, the CCP declared that it is promoting the partial resumption of Chinese traditional culture in order to make Chinese people learn all "outstanding achievements of all civilisations in the world" to serve for "Four modernisations" and "Socialist Construction" (Hua Guofeng, 1978) ${ }^{4}$. Yet in reality all the "outstanding achievements of all civilisations" were mainly referred to as Western cultures in this context.

That is, from the late $19^{\text {th }}$ century, Chinese traditional culture was in great jeopardy, under pressure of Westernisation. And now Chinese political ideology is Marxism, an ideology from Western culture, although at present Marx's doctrine is not popular among Chinese in reality. It can be said that contemporary China's culture is like a mixture, blending with Chinese and western, traditional and modern, capitalist and socialist cultures, and it is named as "modern Chinese culture".

Apart from upper-mentioned voluntary Westernisation, Chinese traditional culture is also seriously challenged by globalisation and Western countries' intended ideological war in the post-Cold War era. The impact of globalisation on China's culture is more serious than imagined. Yet, China has never rejected globalisation and internationalisation from the beginning, partially because globalisation is related to internationalisation, which is positive for China as a developing country to become more modernised, industrialised, and developed, and partially because globalisation as a tendency is hard to reject and resist. Consequently, under the impacts of globalisation, China tends to be more westernised in terms of its culture. Although theoretically Chinese culture can also "go abroad" and engage the West and other cultures, Chinese culture finds it hard to compete with American and Western culture in practice.

The implication is that Western countries (including the United States of America) have successfully "sold" their cultures to the rest of the world (including China) via globalisation, which is considered as (conscious or unconscious) Western cultural imperialism by some scholars (for example J. Schlesinger Arthur, 1974). Clearly, this 


\section{AFRICAN \\ EAST-ASIAN \\ AFFAIRS

process of "selling" their cultures in globalisation is also a process of industrialisation, marketization and internationalisation of Western culture. That is, the spread of Western culture is fit for the capitalist way, it is an efficient business which not only profits those related Western companies but also spreads the Western cultures to the rest of the world at the same time. Furthermore, the West's success is also due to it deftly taking advantage of the similarities between "Western culture" and "modern culture", and to its exercising great power of "international" media, a part of Western capitalist system's great chains.

However, if compared with the West, China lacks the ability to internationalise its cultural industry, including its cultural resources and innovation, and influential "international" media, so the Chinese culture is unable to compete with Western culture at present. In a word, in globalisation, Western, especially American culture, become "globalised culture", yet other cultures in the world (including Chinese culture) do not.

In addition, another challenge to Chinese culture is that it faces the permeation and even attack of Western ideologies, especially after the end of the Cold War. Some Western countries' governments often criticise and scold Chinese political and societal systems and some special policies, and this criticism is always grounded in some would-be universal moralities and values, such as respecting minorities, human rights, social freedom or election rights, and so on. This attack of Western countries has encouraged some Chinese dissents to criticise Chinese political ideologies and create value confusion among Chinese people. Together with the action of Western non-government organisations (NGOs) in China that financially support academic communications and cultural exchanges, Western ideologies' permeation is somehow very successful among some Chinese elites, educated young persons, and even middle-aged women, the latter are not well educated but become the main Christian believers in China ( Wu Guihua, 2012) . $^{5}$

As for Africa, its long history of being colonised by European colonists is also companied with a long history of under-development of the culture. The dark history is marked by the brutal cultural imperialism of European colonial powers in Africa 
AFFAIRS

and the tragic fate of African culture.

By 1912, except for Ethiopia and Liberia, all other countries in Africa had been colonised by some European countries, namely Britain, France, Germany, Belgium, Portugal, Italy and Spain. In reality, the independence of Ethiopia and Liberia was only in name, the state of these two countries was sub-colonised. Under the colonial ruling, African countries became some Western powers' backyards and a part of these colonial empires. For example, those colonised regions in Western Africa were incorporated by the suzerain state France into the "Federation of Western Africa" in 1904, and those equatorial regions into the "Federation of Equatorial Africa" in 1910. Other colonial powers took similar tactics to combine their colonies into one big political system which was mixed with different nations, cultures, identities, regions and customs. Hence there emerged German East Africa, Portuguese African Territory, Belgian Central Africa, and so on. As a result of this struggling for spheres of influence among colonial powers in Africa, on the one hand, African territories and peoples were arbitrarily divided and separated, although between the borders of these different colonies, some nations and ethnicities shared the same traditions and cultures. On the other hand, each colonised region was strengthened through economic, political and cultural linkages with Western suzerain states. Thus colonisation is also a process of African division and overall dependence on Western colonial powers. This process did not change substantially until the success of decolonisation in the 1950s-1960s.

Due to the long history of being under the influence of colonial powers from the $15^{\text {th }}$ century to more or less direct control until the mid- $20^{\text {th }}$ century and the continuous link with the pre-suzerain in many ways, African cultures have become deeply influenced and marked by European culture. This has generally resulted in negative impacts on African culture, although slightly sprouted the fledging modernization in African coast and hinterland.

First, because of colonisation and dependence on suzerains, African education is less developed. In the colonial period, African education was only limited to primary and middle school education, only a few higher education institutions in some big cities 


\section{AFRICAN \\ EAST-ASIAN \\ AFFAIRS \\ THE CHINA MONITOR}

were established after the end of the World War II. In reality, the number of primary schools was also insufficient, and was unable to meet the real demands of Africa countries. In the vast rural areas and most towns, schools for black African people were hard to find. The curriculums of schools were not reasonable either, since they were only copies of suzerain's own systems, and did not match with the real condition and local tradition of Africa. Consequently, African education after decolonialism cannot develop quickly with a lack of resources to be used for the building of national educational systems in Africa after independence.

Second, related to the colonial education mechanism, African elites could not grow to be national leaders, but only the assistants of Western colonists. Obviously, European colonial powers were unable to send their citizens to occupy all positions in African colonies. The colonists selected and appointed those who were educated in suzerains or in colonial schools, and thus likely loyal to suzerains, as the middle and low level rulers in their mother lands. Those educated Africans became a part of the colonial system, maintaining the system's function and efficiency. And these elites in political and societal areas were also elites in culture. Influenced by these elites, African culture was transformed into a copy of Western culture, and the local cultures in Africa were unable to be inherited and carried forward. That made African people unable to shape their own cultural consciousness.

Thirdly, European suzerains' institutions were introduced and duplicated in Africa. Gradually, African people become familiar with and used to European institutional cultures. Even after their political independence, African countries almost accepted the overall coloniser's institutions, especially administrative and judicial systems, and unavoidably those values and ideologies embedded in these institutions, although many African countries desired to reform these institutions. These institutions were less functional, if not flawed.

Fourthly, mainly due to the arbitrary creation of African countries by the colonial powers, the natural growth and evolution of traditional local cultures in Africa was brutally interrupted. Originally, local ethnic groups lived together and shared the same or similar languages, totems, religions, and customs, but were divided and 
forced to live in different countries and meanwhile, in a new "homeland", people in one ethnic group had to live with people in another ethnic group who were culturally and ethnically different. For instance, Haussa are living in Nigeria, Niger, Ghana, Chad, Cameroon, Cote d'Ivoire and Sudan. Conversely, many ethnics with different traditions and cultures were sectioned into one country, like in Tanzania where almost 120 ethnicities live together, and in Nigeria, about 250 ethnicities. Consequently, in general the local cultures were ruptured because of the division of nations, ethnicities and tribes, and meanwhile, the national culture in a new country could not be formed easily due to big differences among different ethnic groups and tribes within a country that cannot be bridged in a short term. Furthermore, the local culture does not have the chance to be consciously classified, inherited, and developed in political, social and economic areas by African people.

Humanistic Education co-operation, cultural independence and significance of Sino-African humanistic education co-operation

Not like scientific and technological education, social sciences and humanistic education cannot get rid of the influence of ideology. In other words, social sciences and humanistic education "is never politically and ideologically neutral" (Samuel Kodjo, 1979). In this sense, the humanistic education can promote the cultural independence of a nation by cultivating citizens' patriotism, self-consciousness on national culture and identity.

The humanistic education, especially on history, literature and language, and philosophy is necessary for developing countries to (re)shape the nationality and consciousness on national unity. That is also the reason that in the beginning of stateestablishment, all developing countries that were independent from suzerains and always included different ethnicities, separated territories and heterogeneous cultures were inclined to construct special narrations on "national history", integrate those different ethnics' literatures and philosophies into official ideology. The newlyformed ideology reflects that the "new nation" shared the same histories, customs, philosophies, traditions, dreams and common future, namely, the shared national identity. Based on the intended humanistic education, a new nation is constructed 


\section{AFRICAN \\ EAST-ASIAN \\ AFFAIRS \\ THE CHINA MONITOR}

and its national culture is formed. This is especially significant for a developing country that was deeply influenced and marked by colonial culture or whose traditional culture was not modernised or not integrated into a shared national culture.

Therefore, humanistic education in formal educational institutions- schools and universities- and in informal education is one basic approach to the construction of a people's consciousness of national citizenship and patriotism, upon which the "cultural consciousness" can be formed. As a concept, "cultural consciousness" means people living in a given cultural circle have the clear self-knowledge on their culture's history, future and its advantages and disadvantages in comparison of heterogeneous cultures ( Fei Xiaotong, 1997) ${ }^{6}$.

Put it in concrete terms, through humanistic education, people can know more about their own culture, then the cultural identity can be formed and the intention to protect local and national cultures is strengthened. If cultural identity and cultural consciousness are formed, the will to refute cultural imperialism could be strengthened and the local and national cultures could be bolstered.

Nonetheless, the humanistic education should take an open attitude towards other cultures, or else it not only makes people have a narrow view on their own nation's culture, and also perhaps makes them hostile towards hetero-culture and encourages cultural nationalism in society. So a closed humanistic education is somehow dangerous and can lead to extreme narcissism and cultural nationalism, which in return damages the cultural diversity and deviates from the original intention of education.

Moreover, the humanistic education without openness to hetero-culture is unable to cultivate national innovation and imagination. It is proved that cultural diversification is a base of human innovation; conversely, non-open humanistic education is an enemy of innovation. In a globalised age, innovation could be a case only if it was understood and accepted by the people in the rest of the world. Namely, based on local and national culture, creative ideas or goods may emerge, but would not have global significance until they are proved to be universal. Or else 
some other ideas and goods similar to them that are commonly understood and accepted in the world will represent them. The so-called "innovation" within a closed culture is not truly innovation since its life-cycle is too short to compete with others. In a sum, the non-open humanistic education is not helpful for national innovation.

Furthermore, to keep one's culture in vigour, it is necessary to keep some competition on it. Without competition and stimulation from hetero-culture, a local culture will gradually lose its vigour, and finally decline to a more obsolete and static state.

To strengthen national identity, inspire national innovation and keep national culture's vigour, the cultural exchange and communication is necessary. Due to this, the humanistic education is significant for both China and Africa, especially in the age of globalisation and when both of their cultures are in crisis.

\section{The achievement of China-African education co-operation and challenges}

There is a long history of China-African communication. It can at least be traced back to Zheng He's voyages toward today's Kenya; however, educational cooperation was initiated only after New China was built in 1949. From then on, SinoAfrican education co-operation experienced a tortuous road. It has made great achievements and is marked by several stages as follows.

Firstly, from the $1950 \mathrm{~s}$ to the $1980 \mathrm{~s}$, the preliminary education co-operation emerged. The first African country that started education co-operation with China was Egypt. Then Egyptian President Nasser had a close private relationship with then Chinese Premier Zhou Enlai. They met in the first Asia-African Conference in Bandung of Indonesia and formed good friendship between China and Egypt. Thus even before these two countries' formal relationship was built in July 1956, the bilateral communication (including educational co-operation) had taken place. In January 1956, the two countries signed an agreement according to which China would receive four Egyptian students to study in China. This as a milestone has some symbolic significance. From then, the first chapter of China-Africa education 


\section{AFRICAN \\ EAST-ASIAN \\ AFFAIRS \\ THE CHINA MONITOR}

co-operation had been unfolded. In the 1950s, a total of 24 students from Egypt, Cameroon, Kenya, Uganda and Malawi had studied in China and three Chinese teachers were sent to Africa. This limited yet unprecedented education co-operation implies both Africa and China needed to enhance their relationship in the time of decolonisation and anti-hegemony, however this co-operation is limited by their local education's low development and limited education resources.

Although there was so many shortages, China, as the "standard-bearer" of developing countries in the Third World in that time (the Soviet Union and the US belonged to the First World), had a great will to support Africa's independence and de-colonisation. So in a very hard time for China in the 1950s-1970s, when China experienced the "Great Leap Forward", terrible "Three Years' Natural Disasters" and the "Great Cultural Revolution", the assistance toward Africa was never reduced but increased. From the beginning of 1950 to the end of 1966, about 164 African students from 14 African countries studied in China, and 14 Chinese teachers had worked in Africa; then in the 1970s, about 648 students from 25 African countries studied in China, and 115 Chinese teachers had been sent to Africa, except for the period of 1967-1972 in which the Cultural Revolution developed. In this period, China not only received general students, but also invited some revolutionary parties' members to study in China as to support Africa's revolution against colonisation and for independence.

Then in the 1980s, with the détente between the East and the West, China-Africa educational co-operation developed more quickly. By the end of the 1980s, about 2245 students from 43 African countries had studied in China, and about 250 students and teachers from China had studied or worked in Africa.

Secondly, in the 1990s China-Africa education co-operation entered into a new stage. With the collapse of the Soviet Union and the end of the Cold War, the ChinaAfrica relationship developed into a new stage, and both China and African countries shifted their policies toward each other. For China, a politics-oriented policy toward Africa was translated into an economy-oriented policy, and a two-track communication between China and Africa was encouraged. That is, apart from 
AFRICAN

EAST-ASIAN

AFFAIRS

government-to-government relations, people-to-people relations were also developed quickly in this time. In the educational field, some self-financed students from Africa were present in Chinese classes. For instance, in the 1990s, there were 1580 selffinanced students of Africa in China, studying various majors. In this period, the number of African students to China that earned Master and Doctor degrees increased, thanks to Chinese government duly increasing the quota of Master and PhD students.

Meanwhile, some independent co-operation agreements and projects were signed between Universities. These agreements and projects were signed and carried on by universities themselves and they did not need the permission of the Chinese government before signing. Chinese universities had the right to develop their education co-operation with African partners, and generally the Chinese Education Ministry would endorse this co-operation financially or by policy. Chinese teachers working in Africa were more often sent by Chinese universities than by the Education Ministry that was the main institution that sent Chinese teachers to Africa before the 1990s. Additionally, Chinese universities also had the rights to do coresearch with African partners and even co-build some laboratories and engage in other co-operation such as discipline construction and personnel training, and so on. By 2003, China's universities had kicked off 43 projects on high-education and scientific research, and built 21 laboratories in African universities.

Thirdly, from the year 2000, a new age of China-African relations emerged, which also greatly influenced on educational co-operation. The first Sino-African ministerial meeting- known as the Forum on China-Africa Co-operation (FOCAC) was held in 2000 in Beijing, and then in turn in Africa and China every 3 years thereafter. From 2006 onwards the ministerial meeting was upgraded into summit meetings, and a longstanding Sino-African co-operation mechanism was formed and developed. Helped by the Forum, Sino-African education co-operation was also developed into a new stage.

In the first Forum, both sides decided to establish the "African Human Resources Development Fund" by which China financially supported Africa's personnel 


\section{AFRICAN \\ EAST-ASIAN \\ AFFAIRS \\ THE CHINA MONITOR}

training and educational development through providing African students with Chinese government scholarships, helping African countries construct laboratories and schools, sending teachers and volunteers to Africa, providing them with Chinese language teaching, and so on. And in reality, the volume of the financial support to Africa by the Fund is increased once every 3 years. By June 2013, China had provided over 45,000 people trainings for Africa, covering more than 20 fields including economics, science and technology, and environmental protection $(\mathrm{Hu}$ Jinxin, 2013). In addition, Chinese language teaching became popular in Africa. The first Confucius Institute, the main institute for Chinese language teaching abroad led by Hanban, was established in Nairobi, Kenya, in 2005. By 2014 there were around 42 Confucius Institutes in 29 African countries and 18 Confucius Classrooms in 13 African countries. With partial assistance from Confucius Institutes, two Chinese studies centres have been established in Egypt and South Africa.

In 2006, China issued the first African Policy Paper, in which education cooperation was highlighted; a second paper has just been published (December 2015). The Chinese government reiterated the importance of the African Human Resources Development Fund and promised "to determine key areas, expand fields, increase investment and improve effectiveness". Moreover, it also promised to increase the number of government scholarship for African students and send more teachers to Africa. The policy paper stated that China will:

Help African countries carry out the teaching of Chinese; implement education assistance projects, promote the development of African weak disciplines; and encourage bi-lateral exchanges and co-operation of educational and academic institutions

The academic co-operation between China and Africa has grown closer in recent years, and several long-term and large-scale co-projects are under implementation, including 20+20 Co-operation Plan of Chinese and African Institutions of Higher Education, Think Tanks 10+10, China-Africa Think Tank Forum and China-Africa Research and Exchange Program, and so on (Obamba, 2013). Meanwhile, some nongovernmental institutions and even some Chinese private enterprises are engaging in 
China-African education co-operation. For example, the first China-African People's Forum was successfully held in Nairobi in 2011. To address Sino-African education co-operation is one of this Forum's missions. In the Forum's China-African Civil Exchange and Co-operation Initiative issued in August 2015, it stated that:

China's civil organisations will help African countries to train and develop all urgently needed talents in fields of technology, engineering, health, agriculture and so on, through aiding the training in China programs, sending experts to and establishing training centres in Africa countries, and granting scholarships to African students.

Although many education achievements in co-operation were made within a halfcentury, there are still several shortages. Firstly, the humanistic education cooperation between the two sides is limited. In the beginning of their educational cooperation, the humanistic education co-operation seemed to be more common than education co-operation in technological and engineering fields (for example, the first batch of African students from Egypt to China studied painting, philosophy and agriculture), mainly because at that time China's education in technology and engineering (except for agriculture) was not developed, and China as a country with a long history and rich cultural heritage could provide international students with some humanistic educational training. However, although some humanistic education co-operation did occur at the early stages of China-Africa education cooperation, it primarily focused on language learning.

From the 1970s, with the increasing demands for industrialisation on both sides, some technological and engineering education co-operation became more important than humanistic education co-operation. Correspondingly, the majors of those teachers sent to Africa were more and more constricted within natural and applied sciences. For example, by the end of the 1980s, about 2245 African students from 43 countries had studied in more than 100 colleges and universities in China (He 2007), mostly majoring in agriculture, computer science, biology, chemistry, biochemistry, medicine, engineering, architecture, water conservancy engineering, food engineering, and some social sciences like economics and international relations. 


\section{AFRICAN \\ EAST-ASIAN \\ AFFAIRS \\ THE CHINA MONITOR}

And Chinese language learning was the main major of those in humanistic majors. Meanwhile, with the implementation of the "Go Abroad" policy", Chinese educational institutions also entered into Africa. By the end of 2003, China had 43 projects on scientific research carried out in 21 African countries' universities. Just as the research fields suggest, educational co-operation mainly focused on science and technology for example on biology, computer science, physics, analytical chemistry, food preservation and processing, materials science, gardening, civil engineering and surveying, and so on.

Of course, since the 2000s, the Confucius Institutes in Africa took over much of the work of teaching the Chinese language to African people. They also introduced some Chinese traditional culture to them, however, this role played by them was beyond the needs of systemic humanistic education co-operation between China and Africa.

Secondly, the forms of education co-operation were limited. For a long time, the main form of educational co-operation was to accept African students to study at Chinese universities and at the same time send Chinese teachers, technicians and volunteers who taught foundational majors like math, physics and chemistry to Africa. In recent years, with the increasing demands in Africa for industrialisation and the development of education in China, the co-operative forms have become relatively richer. More and more co-operation regarding technological and scientific research emerged, and Chinese educational institutions began going to Africa, establishing laboratories, training centres and Chinese language teaching institutions, and especially, helping African countries build educational infrastructure including the construction of schools, providing teaching equipment and learning materials, and so on. However, up to now, the primary form of education co-operation is based on teacher- and student exchanges, co-operation in other forms is not as strong as China's educational co-operation with western academic institutions.

Moreover, to some extent co-operation is like a one-way communication. The students from Africa who go to China are far more than Chinese students studying in Africa. Generally, the USA and Europe are the main destination for studying abroad for Chinese students, Africa is not a popular place for Chinese students to earn their 
degrees. In addition, it is uncommon to see African teachers and scholars visit and do research in Chinese academic institutions, or at least the number is far less than that of Chinese teachers and scholars going to Africa. Clearly it is not absolutely a fit for "co-operation" which implies symmetric and two-way communication.

The Chinese government pays much attention to humanistic exchanges with Africa, and considers education co-operation as part of humanistic exchange between China and Africa. However, it is not clear what the weight or position of humanistic education co-operation in the whole education co-operation and in the humanistic exchange strategy is.

Thirdly, in Sino-Africa educational co-operation, the soft infrastructure building is less important than the hard infrastructure construction. It is more common that China builds houses and rooms for education and training, provides teaching and learning materials, sends teachers to teach technological and engineering courses for African people and so on, than facilitate exchanges on education ideas, approaches, systems and the differences between them. The education itself and areas such as philosophy, culture, and values exchanges through education co-operation are somehow absent in their educational co-operation.

Because of previously mentioned shortages and limitations, humanistic education cooperation in China-Africa education co-operation is not an important part and only on the edge of total education co-operation. In reality, it seems the humanistic education co-operation is somehow absent in the planning for both sides. Consequently, cultures, values and philosophies embedded in humanistic education "carriers" such as books, movies and artwork are not familiar to the audiences of the opposing sides, and each side lacks a third reference of culture to reflect or counterbalance or offset western cultural influences.

\section{Beyond pragmatism: approaches for cultural diversification by Sino-African humanistic educational co-operation}

Although pragmatism-oriented China-Africa education co-operation is important for both sides, it is just the time for both sides to start the humanistic education co- 


\section{AFRICAN \\ EAST-ASIAN \\ AFFAIRS \\ THE CHINA MONITOR}

operation as to resist and counterbalance the Western cultural hegemony, since this influence is deeply undermining the bases of both sides' traditional, national or local cultures and their confidence in cultural independence and their ability to innovate in their modernisation. In order to make more progress in the humanistic education cooperation, some basic approaches should be taken by both sides.

First, a "great education" idea should be formed. "Great education" in China-Africa humanistic education co-operation implies more governmental and academic institutions, more skilful mechanisms, more social institutions and corporations should be involved, and more talents are needed.

The humanistic education co-operation between China and Africa is not only the task of the education ministries of China and African countries, but also is dependent on other governmental institutions' involvement. Clearly, cultural, technological, financial and foreign affairs ministries and some other related governmental institutions are also necessary to ensure the smooth co-operation. In order to keep sound and efficient communication among these ministries and official institutions, a scientific mechanism that maintains good communication and co-ordination among all related governmental institutions and even between governmental and social institutions should be improved.

Furthermore, the humanistic education co-operation should not merely happen between schools or universities, more academic and educational institutions should be engaged too. So as to push the humanistic education co-operation, the cooperation should be encouraged to take place between schools, colleges and universities, think tanks and training centres, and so forth. Additionally, besides governmental engagement, social institutions and even corporations should be encouraged to be involved. Social institutions and corporations can make and flexibly adjust their co-operative projects according to market demands and real situations. In China-Africa education co-operation, governmental institutions and state-controlled academic institutions are main actors, to some degree social and economic actors are absent, which makes the co-operation less effective than imagined and needed. 
Additionally, talents in humanistic education co-operation are key factors, so more funds and materials should be put into talents cultivation and training for both sides.

Secondly, since colonisation (and with globalisation), Africa has been deeply influenced by western cultures, and African cultures and values are not to be applied into the political, judicial, economic and social systems. African cultures and their values are not the main part of political ideologies in African countries, and the local traditional cultures and values do not play the key role as the ruling ideologies in Africa, nor are traditional African cultures well integrated into the west-left colonial cultures, in fact African cultures do not function as a strong or efficient factor in nation building or for economic development, and some traditions such as tribalism has had a negative impact. Under this condition, as to divorce from colonial culture's domination and promote national self-confidence and innovation, African cultures' self-discovery and then self-consciousness are the basic and first step. According to this, China as a rising power that addresses cultural diversification in the world not only has the responsibility but also has great potential, through humanistic education co-operation, to help African countries discover their good traditional cultures and values and assist in modernisation. Additionally, as a state with a long history and rich experiences to sort, inherit and develop traditional cultures (although this is still a challenging and hard work for China), China can do much for African cultural selfdiscovery and consciousness. For this reason, China's educational assistance should somehow financially support more for the African cultures' sorting, developing and teaching within schools and without, co-training talents for African cultures' discovery and sorting, and promoting African local and traditional cultural spread among young people through education and markets. Additionally, China and Africa can also work together to push the pan-African cultural discovery, through cooperation, making African people search for common African cultures and values, promoting African cultural integration and erecting African spiritual independence.

Thirdly, China and Africa can co-operate to write African history books and textbooks from African and developing countries' perspective, gradually getting rid of West-oriented or West-cantered historical narration. Clearly, any independent nation should write its history from its own perspective. So if African countries want 


\section{AFRICAN \\ EAST-ASIAN \\ AFFAIRS \\ THE CHINA MONITOR}

to build their self-cultural confidence and consciousness, one of the first jobs is to form local and national views on their own histories, and this historical narration must be full of the African national heroes, values and moralities, the introduction of African national artistic works and great events, and mostly, the subjectivity of African nations in the historic narration. Other nations and groups (except for some typical countries like South Africa and Namibia where so-called "settler colonies" had made great contribution to the "state-building" in history), including Western colonialists, should be just on the edge of this narration, although they are very important involvers in African history. In this sense, China can financially help African countries to write and publish Africa-cantered history books, build Africacantered museums and art galleries, and train related talents, and so on.

Fourthly, both sides should translate and publish more books, journal and magazine articles for each other, show more movies and TV programs for each other in their respective domestic channels, and organise more joint cultural activities, and so forth. Frankly speaking, both China and Africa have more interest in translating and publishing many kinds of Western books and articles and introducing a large number of Western cultural works than they do each other's. Consequently, in both China and African countries, Western culture is very popular, yet they do not know more about each other, or they know about each other to a great extent from Western perspective through Western media and works. Of course this is not helpful for the diversification of both sides and for the independence and renaissance of the national/local cultures in China and Africa. Although there are some cultural exchanges between China and African countries, for example, several Chinese TV series, like "The Beautiful Time of My Wife" and "We Get Married", which were introduced into Tanzania and Uganda (Yuan Jirong, 2015), due to their weak competitive power of entertainment industry in global arena and the low willingness of exchange, the case of cultural exchanges is still too few, and the area is too limited.

\section{Conclusion}

In the age of globalisation western culture (especially the Anglo-Saxon culture) is 
dominant in the world and cultural diversity and equality are more like a vision than a reality, it is just the time for China and Africa to strengthen their humanistic education co-operation to boom national/local cultures and counterbalance the cultural hegemony of the West within and without. However, in this co-operation there are some matters that should be paid attention to on both sides.

First, for China, it should be aware that there are 54 countries in Africa and huge differences exist among these countries in terms of culture. For example, the cultures, philosophies, moralities, customs and religions are very different between countries in Eastern Africa and those in Western Africa; even in Sub-Sahara Africa, the culture of the East is different from that of the South or the West. In terms of this, China has to clearly understand more African local cultures and take more targeted co-operation with African partners. There is no one-size-fits-all way to co-operate with African countries in humanistic education.

Secondly, the humanistic education co-operation is to address the cultural diversity in both Africa and China, promote the renaissance of Chinese and African cultures and counterbalance the influence of Western culture in the world, therefore the China-African humanistic education co-operation should not aim at penetrating their own cultures into each other and enhance the cultural influence on each other. Cultural penetration is an activity of cultural imperialism. For China and Africa, cooperation in education should promote the self-awareness, self-confidence and independence of national/local cultures. China should not only make more African people aware of China's culture through humanistic education co-operation, but should also help African countries to support their national and local cultures through this co-operation.

Thirdly, although the Sino-African humanistic education co-operation is to counterbalance Western cultures' dominance and resume the confidence and independence of national/local cultures, it definitely does not mean the Western culture should be absolutely excluded in Chinese and African societies. Western culture, as one integral part of cultures in the world, especially in the time of modernisation, should be encouraged to be selectively introduced into developing 


\section{AFRICAN \\ EAST-ASIAN \\ AFFAIRS

countries. The China-Africa humanistic education co-operation is not against the Western culture per se but against its hegemony. Accordingly, Western culture should never be the targeted enemy of China-Africa humanistic education cooperation that would contribute to the cultural diversification locally, regionally and globally.

\section{Endnotes}

1. In this article, the concept of "local culture" is used to refer to culture with specialised characteristics that is a key factor giving an ethnicity or people living in the same region a shared identity. In this sense, the "local culture" in this article can be understood as sub-national culture or regional (transnational) culture in terms of context, differentiated from "national culture" and "global culture".

2. Li Hung Chang, the governor of Shili Province and Commerce Minister, leader of the first Chinese "westernisation movement", in the late Qing Dynasty of China had said in a report for his Emperor that "I think European countries have for decades entered to Southeast Asia from India, then entered China from Southeast Asia, breaking into the hinterland near the border, requiring frontier trade, which were not recorded by history, ... [for China] this is a major change of situation since three thousand years before." in Biography of Li Hung Chang, by Leung Kai Chiu, Hainan Press, July 1993.

3. The first "Westernisation Movement" in China, also termed as self-save movement or self-strengthening movement, is a top-down movement which happened in the $1860 \mathrm{~s}-1890 \mathrm{~s}$, mainly introducing Western military equipment, machine products and science and technology in order to "enrich" China while maintaining a feudal ruling system within the country. It did not make China prosperous and powerful, but it did introduced some advanced western science and technology into China, and led to the emergence of the first batch of modern enterprises in China.

4. [We should] study assiduously the advanced science and technology in the world, 
AFRICAN

EAST-ASIAN

AFFAIRS

and then use them. [We should] assimilate critically ancient Chinese and foreign cultures, selecting the essence, abandoning its dregs, bring forth the new through the old". See Hua Guofeng, "Uniting together, fighting for the construction of Socialist Modernisation", in The Report on the Work of the Government (1978), See people's Daily, March 1978, (online), Available: http://news.xinhuanet.com/siliao/200410/15/content_2094251.htm

5. "As for gender ratio, the Chinese female Christians are obviously more than male ones. In the Christian community, about 69.9 per cent are women. As for the level of education, half of the Christians' education is in primary school level and below. In the Christian community, the number of Christians with primary school education or below accounted for 54.6 percent of the population". Wu Guihua, What's the Number of Chinese Christians? in China National Religious Website, 2 April 2012, (online), Available: http://www.msb.com.cn/html/report/289230-1.htm

6. As a concept, "Cultural consciousness" is put forward for the first time by Professor Fei Xiaotong, a famous sociologist in China, in 1997 at a seminar at Peking University. He used this concept to find a way to deal with interpersonal relations. According to Fei, "Cultural consciousness" is referred to as the clear estimation of his/her/their own culture, and the full understanding on the development of the history and the future of the culture. In other words, it is the selfawareness, self-reflection, and self-creation to his/her own culture. See Fei Xiaotong, On Culture and Cultural Consciousness by Fei Xiaotong, Chinese Qunyan Press, January 2007.

7. The idea "Going Global" was first put forward by Chinese Pre-President Jiang Semin in 1996. On July 26th Jiang proposed in a meeting that "[We should] research how to organise state-owned enterprises to go global".

\section{Bibliography}

China-Africa People's Forum. 2015. The Fourth China-African People's Forum: "China-African Civil Exchanges and Co-operation Initiative" [Online]. 
AFRICAN

Available:

http://www.idcpc.org.cn/stsl/hylt/dsjsfmjlt/cgyxy/201508/ t20150826_76969.html [2015, October 19].

Chiu, L.K. 1993. Biography of Li Hung Chang. Hainan: Hainan Press.

Compiling Group of China Africa Education Co-operation (CGCAEC) (eds.). 2005. China Africa Education Co-operation. Beijing: Peking University Press.

Guihua, W. 2012. What's the Number of Chinese Christians? [Online]. Available: http://www.msb.com.cn/html/report/289230-1.htm [2015, November 20].

Hanban. 2014. About Confucius Institutes [Online]. Available: http:// english.hanban.org/node_10971.htm [2015, November 20].

He Wenping, 2007, "The Summary of China-Africa Education Exchange and Cooperation: Stages and Future's Challenges", Western Africa Journal, Vol.3, 2007.

Jinxin, H. 2013 China-Africa Hand in Hand, Good News for Global--sidelights of Sino-Africa Investment Summit [Online]. Available: http:// paper.people.com.cn/rmrbhwb/html/2013-06/01/content_1248274.htm[2015, November 20].

Jirong, Y. 2015. Chinese TV Drama Hits Africa, People's Daily (Overseas Edition), 5 January.

Kodjo, S. 1979. Educational Strategy for Cultural Independence in West Africa. Journal of Asian and African Studies, 14(1-2): 67-77.

Obamba, M. 2013. The Dragon's Deal: Sino-African Co-operation in Higher Education. International Higher Education, 72, Summer: 7-8.

Schlesinger, A.M. 1974. The Missionary Enterprise and Theories of Imperialism in J.K. Fairbank (ed.). Missionary Enterprise in China and America. Cambridge, M.A.: Harvard University Press. 
AFRICAN

EAST-ASIAN

AFFAIRS

UNESCO. 2001. UNESCO Universal Declaration on Cultural Diversity [Online]. Available: http://portal.unesco.org/en/ev.phpURL_ID $=13179 \& U R L \_D O=D O \_T O P I C \& U R L \_S E C T I O N=201 . h t m l \quad[2015$, November 20].

Xiaotong, F. 2007. Culture and Cultural Consciousness. Beijing: Qunyan Press.

Xinhua. 1978. The Report on the Work of the Government [Online]. Available: http://news.xinhuanet.com/siliao/2004-10/15/content_2094251.htm [2015, November 20].

Xinhua. 2006. China's Africa Policy Paper [Online]. Available: http:// news.xinhuanet.com/world/2006-01/12/content_4042333.htm [2015, November 20].

Xinhua. 2011. Education Co-operation Has Become Important Contents of ChinaAfrican Humanistic Exchanges [Online]. Available: http:// news.xinhuanet.com/overseas/2011-07/16/c_13989339.htm [2015, November 20]. 